\title{
Increasing attractiveness and image recognition of Bulgaria as a tourism destination
}

\author{
Aumento da atratividade e reconhecimento da imagem da Bulgária como destino turístico
}

\author{
Preslav Mihaylov Dimitrov \\ South-West University "Neofit Rilski", Faculty of Economics, \\ 66 Ivan Michailov st. 2700 Blagoevgrad, Bulgaria, preslav.dimitrov@swu.bg \\ Mariya Zlatkova Stankova \\ South-West University "Neofit Rilski", Faculty of Economics, \\ 2700 Blagoevgrad, Bulgaria, mzlstan@yahoo.com \\ Ivanka Vasenska \\ South-West University "Neofit Rilski", Faculty of Economics, \\ 2700 Blagoevgrad, Bulgaria, ivankav@abv.bg \\ Dimitria Uzunova \\ South-West University "Neofit Rilski", Faculty of Economics, \\ 2700 Blagoevgrad, Bulgaria, duzunowa@abv.bg
}

\begin{abstract}
The concept of tourism destination attractiveness does not constitute a new topic in the scientific literature in the field of tourism. On the contrary, attention has been brought towards it since last century's 60 years. For a relatively long period, however, the existing studies show out that they not only did not lead to the creation of a single platform for evaluation, but rather have resulted in a fragmentation of the researchers' opinions. At present, numerous authors have been trying to identify the destination's attractiveness and factors influencing tourists' decision-making process to assess a given area as a desirable vacation spot. The attractiveness of the area does not only depend on the characteristics of its corresponding site and the local population, but also from tourist cognitive image perception of the destination. The present paper comprises the results from two separate studies conducted in parallel from 2011 to 2014 and it aims to outline the various factors that could influence the process of increasing of attractiveness and image recognition of Bulgaria as a tourism destination. For this purpose, a multifactorial analysis of the whole tourism destination of Bulgaria was applied alongside with a cultural profiling of an almost iconic and landmark micro destination for cultural tourism such as the town of Plovdiv (or the ancient Phillipopolis found by the king Phillip the Second, the father of Alexander the Great).
\end{abstract}

Keywords: Tourism destination attractiveness, image recognition, factor analysis, semantic analysis.
Resumo

O conceito de atratividade do destino turístico não constitui um novo tópico na literatura científica no campo do turismo. Pelo contrário, a atenção foi focada nesse tema desde os últimos 60 anos do século passado. Por um período relativamente longo, no entanto, os estudos existentes mostram que eles não só não levaram à criação de uma única plataforma de avaliação, mas que resultaram numa fragmentação das opiniões dos investigadores. Atualmente, numerosos autores têm tentado identificar a atratividade do destino e os fatores que influenciam o processo de tomada de decisão dos turistas para avaliar uma determinada área como um local de férias desejável. A atratividade da região não depende apenas das suas características físicas e da população local, mas também da perceção da imagem cognitiva turística do destino. O presente trabalho compreende os resultados de dois estudos separados realizados em paralelo de 2011 a 2014 e pretende esboçar os vários fatores que podem influenciar o processo do aumento da atratividade e reconhecimento da imagem da Bulgária como destino turístico. Para tal, foi feita uma análise multifatorial do destino turístico Bulgária como um todo e foi aplicada ao lado de um perfil cultural de um micro-destino quase icónico e histórico para o turismo cultural, como a cidade de Plovdiv (ou a antiga Phillipopolis, fundada pelo rei Filipe II, O pai de Alexandre, o Grande).

Palavras-chave: Atratividade do destino, reconhecimento da imagem, análise fatorial, análise semântica.

\section{Introduction}

Bulgaria is situated in South-eastern Europe and in the northeastern part of the Balkan Peninsula. It is a European, Balkan, Black Sea and Danube country. This geographic positioning and crossroads position in relation to Europe and Asia and define its strategic location on the political map of Europe and the Balkans, in terms of the movement of international tourist flows. The affirmation of attractive, positive image of our country as a destination situated near the established European tourism centres has been under the influence of our membership in the European Union. In recent years it has an impact on tourism development in the country. Moreover, facilitated border and customs control, free movement of people, capital, goods and services and innovations have been advantages to Bulgaria ever since its EU joining.

The present research paper aims to highlight approaches for tourist destination Bulgaria attractiveness increasing via its cultural image recognition. Thus can be achieves through the use of four-step process as, follows:

- Evaluation of the overall attractiveness of tourist destination Bulgaria;

- Multifactorial analysis of the whole tourism destination Bulgaria;

- Cultural profiling of a landmark micro destination; 
- Drawing of conclusions and recommendations in order to increase the attractiveness and the image recognition of the tourist destination.

The city of Plovdiv is the second largest city in Bulgaria, situated in the central part of the Upper Thracian Plain on the two banks of the Maritsa River, which divides it into two parts, at an area of 101,981 square meters and with a population of 345,249 people. The distance between Plovdiv and Sofia, the capital city of Bulgaria, is $147 \mathrm{~km}$., and to Plovdiv airport - $10 \mathrm{~km}$. Plovdiv is the administrative centre of the South Central Region, which includes five districts. Plovdiv is one of the oldest cities in Europe, older than Rome, Athens and Constantinople and contemporary of Troy. Due to the fact that it is situated at the foot of seven hills, it is often called the city of seven hills. Its cultural and historical legacy dates back to the Thracians, who are the most ancient population on the Balkan Peninsula, for which written sources have been found. During the ages numerous nationalities, ethnical groups and religions coexisted in Plovdiv thus providing grounds for its multicultural faces. Its rich cultural, historical and archaeological heritage, as well as its atmosphere makes it a centre of attraction and an attractive destination for cultural tourism. Moreover, the landmark micro destination of the Old Town of Plovdiv is a favourable location both for tourist and locals.

\section{Literature review}

On one hand, the attractiveness of a destination reflects its visitor's feelings and opinions of about its perceived ability to satisfy their needs. Without the attractiveness there is no tourism and there could be little or no need for tourism facilities and services. It is only when people are attracted to a destination services the facilities follow (Ferrario, 1979). The more a destination is able to meet the needs of the tourists, the more it is perceived to be attractive and the more the destination is likely to be chosen. Researchers have identified tourist destination attractiveness by analysing its attributes (Gearing, Swart \& Var, 1974; Ritchie \& Zins, 1978; Tang \& Rochananond, 1990). Mayo and Jarvis (1981), define attractiveness as, "the perceived ability of the destination to deliver individual benefits". This ability is enhanced by the attributes of a destination, i.e. those components that define a destination. The importance of these attributes help people to evaluate the attractiveness of a destination and make relevant choices. Hu \& Ritchie (1993, p. 25) determine the attractiveness of a tourist destination as "feelings, beliefs, and opinions that a person has the about the ability of a tourist destination to provide satisfaction in terms of one's specific holiday needs". Lue, Crompton and Stewart (1996, p. 43) summarize attractiveness as "something recognized by individual tourists as a factor that influences their decision making when selecting a tourist location where one can enjoy a tourist vacation". According to Formica (2000, p. 35) even services emerging around the tourist destinations frequently alone embody its attractiveness. Attractiveness is perceived as an important perception by tourist when they intend involve themselves in tourism activities (Funk, Ridinger, \& Moorman, 2004). Kotler \& Armstrong (2014) described destination attractiveness as a capacity perceived by tourist's to satisfy their needs. Middleton (1989) also asserted that "attractiveness" is the initial motivation for tourists to choose a destination, according to their interests and preferences (Benckendorff \& Pearce, 2003). "Attractiveness" is seen as an important perception of tourists when they participate in a tourism activity (Funk \& al., 2004) and is also defined as "a permanent resource" or "permanent construction of a tourism destination". Attractiveness allows the public to achieve entertainment with interest and has educational functions (Hu \& Wall, 2005; Leask, 2010) and the strength of destination attractiveness relates to the economic development and performance of the region (Andersson \& Getz, 2009).

Given the current situation on the tourist market and the growing competition, all tourist destinations are facing the challenge of establishing a profile which takes into consideration the internal and external way of perceiving the destination, since the available inconsistency (discrepancy) between the way of perceiving the destination by tourists and by local community would impediment the formation of a clear profile. Lack of particular position inevitably leads to identical offering which on its part enhances the interchangeability with potential competitive destinations, and the final result is displacement of one or another destination from the tourist market.

On the other hand, formation of a cultural destination profile is largely related to the authenticity and image, and in this connection it should be underlined that the focus is on what is actually perceived as authentic and what is not, since the degree of satisfaction depends much more on the "needs, expectations and experience of the perceiving, and is in fact a category of perception" (Vester, 1993). This means that authenticity could be difficult to define, and should be understood as a projection of what in the mental picture of both tourists and local community is undoubtedly and ultimately connected with tourist destination. In the identification of that authenticity, which is perceived as such by both groups, we must seek the foundations of profiling, which on its part will have positive impact on the image of the destination.

Furthermore, Bieger (2002) defines the image as a combination of objective knowledge and subjective emotions, which is marked by the way of perceiving by the guests, and on the part of offering it can be influenced only indirectly (Bieger, 2002). This definition brings to the front the role of subjective perception which greatly varies and depends on a number of factors, such as views, education, social status, income, age, etc. This, on its part, means that the image would be perceived differently by the different groups of tourists, and this aspect is very important for the capability to influence the image, which is permanently subject to change. This fact leads to the key aspects of the very profiling, i.e.: specific competences, distinction from the competition, focusing on certain target groups and target markets, emotions and dramaturgy in the tourist offering, coordination of the many single products, adequate and consistent communication of the profile (Bieger, Pechlaner, \& Steinecke, 2001). Each one of these aspects has its own importance for the formation of a clearly identifiable destination profile. The specific competences may be viewed upon as a basis of profiling because they are these unique features of the destination which distinguish it from competitors. The focus on certain target groups attains special importance in respect of cultural profiling as consumers of cultural tourism, and in particular the specific cultural tourists are distinguished with their high social-and-economic status and high educational level which refers to their more demanding requirements and expectations. In this connection, Steckenbauer (2004) looks upon cultural supply at the background of the theory of the forms of capital by Bourdieu (1986), according to which the symbol capital is more or less a synonym of prestige and reputation, and in this sense, the more 
symbol capital is "loaded" into the cultural offering, the more attractive and demanded it is because of the fact that it allows distinction from the other tourists, as well as of the fact that it is perceived as highly prestigious. The specific features of the target groups should find expression in the formation of the cultural profile of the destination, and the opportunity for prestigious consumption and distinction from the mass tourists may be viewed upon as a motivation factor, as Vester (1999) even considers an approach should be identified by which to show (manifest) the cultural tourist who is not "simply" an ordinary tourist.

Moreover, the fact that the cultural consumption is related to a strong emotional influence cannot be ignored. Co-experiencing historical events, a visit to various places evidencing the development of mankind in the course of time, "diving" in the world of arts, getting familiar with dissimilar cultures bring forth different emotions in people. Emotions which open a different world, a world of the deeply spiritual, which adds uniqueness to cultural tourism and turns into experience. The sense of experience relates to the events, but it is dependent on the subjective processes of perceiving the event, therefore two individuals cannot live through one and the same experience (Richards, 2001). This means that every individual establishes its own subjective field of experiences in the course of time, which greatly depends on the (cultural) socialization. Experience cannot be felt identical by everyone, but at least preconditions can be created, as well as enhance the likelihood to experience something culturally valuable and deeply moving. In this sense, cultural supply should be able to find the approach to the strongly desired consumption and secure the necessary premises for the implementation of its nature and achievement of a clear and attractive cultural profile. According to Becker (1992) and Steinecke (1994), in the shaping of cultural offering, one must keep to the following conceptual requirements:

- Credibility and authenticity of cultural tourist offering;

- Responsible attitude and taking the necessary measures by the internal marketing for prevention of the threat to the cultural legacy;

- Involvement of local community (in particular, those occupied in the industry) in the shaping of the offering;

- Intensive joint work between academic circles from the area of culture and tourism and those practicing in both spheres;

- Professional use of advanced marketing methods;

- Compatibility between culture and consumption; it is necessary to develop supply, rich in experiences, in attractive environment.

From the above requirements, it is evident that in the process of both shaping the cultural supply and formation of the cultural profile of the destination, only joint responsible work of all stakeholders may provide authenticity preservation the and protection of the cultural wealth. To achieve these targets would be impossible without consistency of the actions and coordination of the activities performed by the numerous participants in the process of formation of the products of cultural tourism (Stankova, 2006).

It will be interesting to highlight the relation between the established destination profile and the brand which can be described in the following manner: one well performed and clearly represented profile can be defined as a brand (John-Grimm, 2006). This means that a clear and attractive profile converts the destination into brand which is distinguished from the rest and characterized by a high degree of recognition. In this context, the awareness of the brand as an approach of sending message to mainly two target groups, the consumers aspiring after quality, and those aspiring after prestigious consumption (Wöhe, 2000), leads once again to the theory of the symbol capital by Bourdieu, and consequently to the association with the cultural tourists who are distinguished with high demands and expectations in respect of tourist products, as well as in respect of having the opportunity to be different from the other types of tourists. Some authors even underline that the selected destination is less implementing the personal needs, and much more outlining the image of the tourist in society and his/her belonging to the corresponding social group, through the image associated with the destination (Caldwell \& Freire, 2004). In this sense, the formation of a clearly recognizable and attractive cultural profile which is to convert the destination into brand, associated in the conceptions of tourists not only with the opportunity to receive new knowledge and awareness of the cultural wealth, but also with the opportunity to show distinction and prestigious consumption, attains key importance.

Given the above specified features of cultural profiling and its importance for the destination, the need of analysis and evaluation of the cultural profile comes to the front for the purpose of taking possible corrective and/or supportive actions.

\section{Methodology}

Object of the research is the analysis of the attractiveness of a tourist destination Bulgaria. The focus is aimed at establishment of the benefits that increased attractiveness provides to all stakeholders and its role for consumers anticipated cognitive destination image recognition during their vacation decision-making process.

The conceptualization of the tourist destination attractiveness given by Mayo and Jarvis (1981:2013) has been still applied as operationalizing tool for destination's image. Scientific research in Tourism indicate that for tourist destination attractiveness study most commonly are used the assessment methods based on the opinions of prospective visitors, respectively tourists. The work of Geaing, Swart, \& Var, (1974) provides method for measuring the relative importance of seventeen factors (or attributes) which may influence the tourist's evaluation of a particular destination. Var, Beck, \& Lofius, (1977) applied the same methodology that Gearing et al., (1974) proposed. Ritchie and Zins (1978) determined the factors (in order of importance) affecting the attractiveness of Quebec, Canada as a tourist destination by implementing the Gearing et al. (1974) seventeen criteria they have established eight factors that influence the attractiveness of the destination. Hu and Ritchie (1993) evaluated with ratings 400 respondents' opinions on destination attractiveness via the contextual approach. Their method is referred to as a multiattribute situational attitude measurement model that generates a numerical index of touristic attractiveness influencing in a way the image recognition of the perceived attractiveness. Chen and Hsu (2000) explored the image attributes which are collectively the leading attributes measuring the total attractiveness of a destination and which influence the consumers' destination choice. Namely, trip planning timeframe, budgeted travel costs, and length of the travel.

For the purposes of this paper tourism is unified as any user experience with delight that has been expected and remembered by 
many consumers as a very important aspect of their lives. By supporting the above assertion below we intend to elaborate analysis of survey data on opinions of 624 international tourists visited Bulgaria in the period May 2013 to December 2014, while conducting two types of data analysis. These analyses are based on electronically conducted survey, which aimed to grasp the largest possible sample of relevant market segments - international tourists from Greece, Turkey, Russia, Macedonia and Germany. Those foreign markets are not only accepted as generating in terms of tourism in Bulgaria (Strategy for Sustainable Tourism Development, Ministry of Tourism, 2013), but these markets are sending one of the largest permanent tourist flows in our country.

Following the views of the actual consumers we intend to examine how surveyed respondents of the six largest generating markets Bulgaria's attractiveness. Attributes of tourist destination include elements such as landmarks, infrastructure, services, accessibility, affordability and other complementary components. These attributes together make up the total or overall attractiveness of natural and anthropogenic resources that exist on any given destination. Since these elements are different in nature, researchers found it difficult to develop measurement methods to analyse, evaluate and compare the diverse characteristics of tourist destinations. As Formica (2000) states as any museum or lake is unique in what it offers and its appearance cannot be described as identical to other tourist resources listed in the same category. However, according to the previous studies, there are two ways to measure the attractiveness of the destination. The first can be achieved by studying the sights and second - by examining perceptions of tourists attracted to a given destination attractiveness.

Attributes of tourist destination attractiveness, hereinafter referred for the purposes of this study "factors", derived from Gearing et al., (1974) and later modified by Ritchie and Zins (1978) in their versions enumerated herein below, are extensively applied towards tourist destination attractiveness assessment (See Table 1).

\section{Table 1: Attributes and sub attributes (factors) of tourist destination attractiveness}

\begin{tabular}{|c|c|}
\hline $\begin{array}{l}\text { Attributes of tourist destination } \\
\text { attractiveness }\end{array}$ & Sub attributes \\
\hline 1. Attributes of Natural Resources. & $\begin{array}{l}\text { - beautiful nature beauty of the landscape } \\
\text { - climate, } \\
\text { - water resources } \\
\text { - flora and } \\
\text { - fauna }\end{array}$ \\
\hline 2. Attributes of Culture. & $\begin{array}{l}\text { - architectural and historical artefacts and } \\
\text { - archaeological sites, authentic cuisine, } \\
\text { - festivals } \\
\text { - religious rites, } \\
\text { - local authenticity } \\
\text { - Accommodation and catering }\end{array}$ \\
\hline 3. Attributes of the superstructure. & $\begin{array}{l}\text { - facilities for outdoor entertainment } \\
\text { - facilities for maintaining physical fitness, }\end{array}$ \\
\hline 4. Attributes of infrastructure. & $\begin{array}{l}\text { - nightlife and shopping district } \\
\text { - social, utilities, communications, transportation structures } \\
\text { - accommodation } \\
\text { - power supply and communications } \\
\text { - Water and sewerage structures. }\end{array}$ \\
\hline 5. Attributes of accessibility. & $\begin{array}{l}\text { - physical distance and } \\
\text { - time to reach to and from your destination. }\end{array}$ \\
\hline 6. Attributes of hospitality. & $\begin{array}{l}\text { - information centres, language and translation services } \\
\text { - instructional pedestrian signs, maps and local guide services, } \\
\text { - respect the local population to tourists }\end{array}$ \\
\hline 7. Attributes of additional services. & $\begin{array}{l}\text { - banks / ATMs, currency exchange, } \\
\text { - police, health and medical services. }\end{array}$ \\
\hline 8. Attributes of price / cost. & $\begin{array}{l}\text { - the cost of basic goods and services - accommodation and } \\
\text { - feeding and } \\
\text { - transport }\end{array}$ \\
\hline
\end{tabular}

Source: Authors' own elaboration based on Gearing et al. (1974) and Ritchie and Zins (1978).

The instrument for this study is based on primary data - from a survey of closed questions circulated electronically among tourists visited Bulgaria for the period from May 2013 to December 2014; and secondary data provided by the Ministry of Tourism (previously a part of the former Bulgaria's Ministry of Economy, Energy and Tourism, which existed up to 2014). Most of the questions are based on or are adapted from those already mentioned above research models, in particular research on measuring the attractiveness of the tourist destination. The questionnaire used five-point numerical Likert scale ranging from 1 - not attractive to 5 - extremely attractive to measure affective evaluation of tourists or preference to the destination. The same type of numerical scale ranging from 1 - least important to 5 - the most significant is used to assess the cognitive perception of tourists and their perceptions about the importance of the attributes that contribute to the attractiveness of the destination. The survey consists of three parts; each is designed to produce answers for the following groups of questions:

Part I - Evaluation of the attractiveness of the tourist destination (measurement of affect or preferences or at the main weights);

Part II - Evaluation of the importance of sub-attribute (measuring the cognitive perception or perception / desire);

Part III - Basic information of respondents. 
The implementation of the survey is carried out consistently and serves the purpose of factor analysis, which is conducted on the basis of two main procedures. The first procedure involves coding variables and analysis of the profiles of the respondents. The second procedure involves analysis of the perceived attractiveness of tourist destination and an analysis of the perceived importance of the destination attributes. Also to confirm the structure of the factors or attributes on the scale of importance is attached before further analysis of the perceived importance of the attributes of the destination. The analysis of the overall attractiveness of the destination and the connection with the possible intention to repeatedly return of tourists it was also investigated. In addition, the relationship between internal and external features of the tourists and the perceived importance of the attributes of the destination are investigated. The procedures that were undertaken are described as follows:

Step 1: Analysis of the profile of the participants.

Descriptive statistical techniques, namely frequency and percentages as provided in the module of SPSS for Windows, are used to analyses the profile of the participants.

\section{Step 2: Analysis of perceived attractiveness}

To answer the question: How, tourists from six countries of origin perceived attractiveness of Bulgaria? "Arithmetic average $(x)$ and standard deviation (SD), were calculated using SPSS software package.

Step 3: Confirmation of the structure of the factors in the scale of importance.

To check the orthogonal measured factors in factor analysis is conducted Varimax Rotation. Latent root criterion is 1.0 and is used for extracting the factors and factor loadings of .40, to set the order of inclusion of attributes (Hair, Anderson, Tatham, \& Black, 1998; Nunnali, 1978).

Step 4: Analysis of the perceived importance of the attributes of the destination

This step answers the question: "How tourists perceive the importance of destination attributes that contribute to the overall attractiveness of the destination". Like calculating the perception of attractiveness, the answer is achieved by using descriptive statistical approaches and arithmetic mean ( $\mathrm{x}$ ) and standard deviation (SD) using SPSS.

In addition, 30 sub-attributes were tested by factor analysis, in order to check in advance whether the attributes of the area applied by Guaring al. (1974) and Ritchie and Hu (1978), which are the main dimensions of scale and our work are applicable for the purposes of the research.

All tested variables were coded and grouped into three categories used accordingly to the applied scales. 611 (96.30\%) valid questionnaires out of 624 filled by respondents were coded according to the variables. These variables are put into the following groups:

1) Thirty-eight interval-scaled dependent variables (interval-scaled dependent variables) (8 basic factors - with accordance to those mentioned in Table 1, or attributes to assess the attractiveness of the destination in Part 1 of the survey and 30 sub-attributes to assess the perceptions of the importance of attributes in Part 2).

2) Ten-scaled nominally independent variables (in terms of psychological and socio-demographic data of respondents for their assessment of changes in the perceived importance of the attributes of the destination differentiated by internal and external characteristics of tourists in Part 3 of the questionnaire).

3) The display is a nominally scaled dependent variable (related to possible future intention of tourists visit the destination again in Part 4). After this task, the results obtained from the ratings of the respondents were entered into SPSS $\subseteq$ module numbering and further analysis. All the values collected for the above variables are then introduced to SPSS modules for further analysis.

To answer the question: "How tourists from the six countries of origin perceived attractiveness of the destination?", the participants were asked to rate each of the eight attributes of attractiveness on a scale of one to five points based on their perceptions of attractiveness that tourist destination Bulgaria holds. Boasting the simple average was used to obtain an average score for each attractiveness factor /attribute. The value obtained is represented by the model to measure the attractiveness and refers to the evaluation aspect or the perception of each of the eight destination attractiveness attributes.

\section{Results}

In order to establish what is the relative importance of attributes that influence the overall attractiveness of the destination was employed Varimax rotation of factor analysis. A successful factor model requires interpretation of factors found within the subject area. To facilitate this interpretation is rotated, usually by the Varimax method. Factor rotation aims to increase of a factor weights expense of others, thereby striving is any observed variables to find an explanation using a possibly smaller number of factors. The calculation of eigenvalues, the factor weights, performing rotation and finding factor results are complex computational procedures are performed using SPSS.

Among the many methods, facilitating interpretation of factors, perhaps the most popular is the method of Varimax rotation. The idea of Varimax rotation is to change the factors that they can keep their good properties (completeness of the description of the sample as a whole) and to get better interpretive qualities. Redistributed are factors weights such as the high rise and small decrease, which leads to the fact that each factor can be explained by a small number of variables. In our case, of 30 factors is limited to 8 , representing $59.05 \%$ of the elaborated above. This means that variables with large loads (greater than 0.40), signal correlation with variable factors which have been introduced. In the treatment process, some variables registered loads 0.39 (Climate) and 0.38 (Water Resources), which, although not matching pledged our load, with some acceptable levels and we let them leave like Gearing at al. (1974) and Ritchie and Zins (1978), cited by Morachart (2003). Profitability analysis (Cronbach's alpha) has been calculated in order to prove the reliability and internal consistency in each of the factors. The results demonstrate that alpha coefficients for the eight factors examined by us ranged from 0.76 to 0.79 (see Table 2), well above the minimum value of 0.50 , set for the reliability of a research (Hair et al., 1998; Noonan, 1978; Hair, J.F., Black, W.C., Babin, B.J., \& Anderson, R.E. 2010). 
Table 2. Multifactor analysis on the importance of attributes / factors

\begin{tabular}{|c|c|c|c|c|}
\hline Factor Importance & Factor loadings & Eigenvalue & Explained Variance \% a & Reliability b \\
\hline $\begin{array}{l}\text { Factor 1: Services } \\
\text { Banks / ATMs, currency } \\
\text { exchange; police; } \\
\text { Medical / health services. }\end{array}$ & $\begin{array}{l}0,44 \\
0,64\end{array}$ & 7.190 & 23.965 & .76 \\
\hline $\begin{array}{l}\text { Factor 2: Natural } \\
\text { natural beauty } \\
\text { climate } \\
\text { water resources } \\
\text { flora } \\
\text { fauna }\end{array}$ & $\begin{array}{l}0,70 \\
0,39 \\
0,38 \\
0,78 \\
0,80\end{array}$ & 2.34 & 8.111 & .78 \\
\hline $\begin{array}{l}\text { Factor 3: Cultural } \\
\text { Architectural cultural and } \\
\text { historical artefacts and } \\
\text { archaeological sites } \\
\text { authentic cuisine, } \\
\text { festivals } \\
\text { religious rites, } \\
\text { local authenticity }\end{array}$ & $\begin{array}{l}0,65 \\
0,70 \\
0,49 \\
0,70 \\
0,57 \\
0,64\end{array}$ & 1.661 & 5.536 & .78 \\
\hline $\begin{array}{l}\text { Factor 4: Hospitality } \\
\text { information centers, } \\
\text { language and translation } \\
\text { services } \\
\text { Instructional pedestrian } \\
\text { signs, maps } \\
\text { local guide services } \\
\text { respect the local } \\
\text { population to tourists }\end{array}$ & $\begin{array}{l}0,63 \\
0,68 \\
0,68 \\
0,59\end{array}$ & 1,513 & 5,043 & .76 \\
\hline $\begin{array}{l}\text { Factor 7: Infrastructure } \\
\text { transportation structures } \\
\text { accommodation } \\
\text { communications } \\
\text { electricity / water supply } \\
\text { and sanitation }\end{array}$ & $\begin{array}{l}0,63 \\
0,54 \\
0,70 \\
0,63\end{array}$ & 1.139 & 3.797 & .77 \\
\hline $\begin{array}{l}\text { Factor } 8 \text { : Recreation } \\
\text { outdoor facilities } \\
\text { facilities for maintaining } \\
\text { physical fitness } \\
\text { nightlife and shopping }\end{array}$ & $\begin{array}{l}0,66 \\
0,58 \\
0,64\end{array}$ & 1.055 & 3.515 & 3.315 \\
\hline
\end{tabular}

Source: Authors' own calculation based on the data of the performed questionnaire survey.

According to respondents, most critical points related to the impact of traffic noise, water pollution and air pollution (at most in urban areas and cities). In order to reduce the air pollution caused by the vehicles, both of the private and the public transport it is advisable they to be changed from conventional to one using unconventional fuel. Furthermore, more recycling facilities are in demand for both public areas and for individual households. The comments are clearly at the heart of depreciation the natural factors attractiveness. With accordance to this study, in a study initiated by the Ministry of Economy, Energy and Tourism (2013) for destination Bulgaria image positioning among potential Bulgarian and foreign tourists have outlined that our country is perceived as a destination that is "far from the idea cleanliness, security and development", having actually existing "infrastructural issues" and "outstanding issues with low hygiene and neglect ".

4.2 Multifactorial analysis of the whole tourist destination Bulgaria

Table 3 displays results of ranking the evaluation of surveyed tourists for the eight identifying attractive attributes. The most appealing attributes within the overall attractiveness of a tourist destination Bulgaria $(\bar{x}=3,80, \sigma=.87$ ) according to of the tourists were cultural attributes determined by architectural and historical artefacts, archaeological sites, carnivals and festivals, religion and religious rites and authentic cuisine. Furthermore, hospitality, which refers to information centres, language and translation services, pedestrian Instructional signs, maps and local guide services, attitude of local people towards tourists, local tourist guides and tour services, attitude of local people towards tourists, were ranked second $(\bar{x}=3.77, \alpha=.77)$. 
Table 3. Overall attractiveness as a tourist destination Bulgaria displayed according tourists' opinion from the six generating markets

\begin{tabular}{|c|c|c|c|c|c|c|c|c|c|}
\hline \multirow[b]{2}{*}{ Attributes } & \multicolumn{6}{|c|}{ County of Origin } & \multirow[t]{2}{*}{$\bar{x}$} & \multirow{2}{*}{$\begin{array}{l}\text { CO } \\
\sigma\end{array}$} & \multirow{2}{*}{ 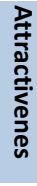 } \\
\hline & 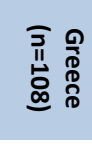 & 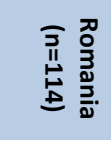 & 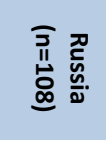 & 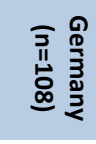 & 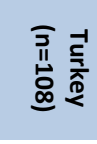 & 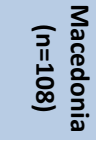 & & & \\
\hline Cultural & 3.8 & 3.9 & 3.74 & 3.88 & 3.37 & 4.1 & 3.8 & .87 & 1 \\
\hline Hospitality & 3.87 & 3.89 & 3.59 & 3.87 & 3.64 & 3.72 & 3.77 & .77 & 2 \\
\hline Price/Cost & 3.73 & 3.84 & 3.36 & 4.00 & 3.36 & 3.77 & 3.75 & .95 & 3 \\
\hline Nature & 3.74 & 3.67 & 3.70 & 3.71 & 3.17 & 4.12 & 3.68 & .95 & 4 \\
\hline Services & 3.81 & 3.56 & 3.91 & 3.83 & 3.36 & 3.64 & & & \\
\hline Recreation facilities & 3.63 & 3.55 & 3.61 & 3.56 & 2.93 & 3.45 & 3.47 & .98 & 5 \\
\hline Accessibility & 3.41 & 3.46 & 3.42 & 3.56 & 2.99 & 3.11 & 3.32 & .88 & 7 \\
\hline Infrastructure & 3.05 & 2,85 & 3.32 & 3.11 & 2.47 & 2.95 & 2.93 & .95 & 8 \\
\hline
\end{tabular}

Source: Authors' own calculation (2014/2015), based on the data of the performed questionnaire survey.

The ratio of price / cost, which determined the price paid for basic goods and services to tourists (accommodation, meals and transportation within the destination) are with the third-largest value $(\bar{x}=3.75, \sigma=.95)$. Surprisingly for us, natural attributes, including a natural beauty, climate, water resources, flora and fauna, were positioned only on the fourth place $(\bar{x}=3.68, \sigma=.95)$. Additional services described above as banks / ATMs, currency exchange; Police, health and medical services; $(\bar{x}=3.67, \sigma=.92)$, were ranked next fifth in perceived importance in the mix attractive tourist destination Bulgaria. Recreational and commercial facilities including outdoor facilities, entertainment for maintaining physical fitness, nightlife and shops were rated by respondents as less attractive and their weight is the sixth-largest in total score $\left(\bar{x}=3.47, \sigma^{\prime}=.98\right)$.

Availability, which is shorthand for the physical distance and time to reach to and from the destination is the penultimate seventh place $(\bar{x}$ $=3.32, \sigma=.88)$. Finally, quite rightly in our view, tourists ranked the attribute Infrastructure, which include social, utilities, communications, transportation and structures on the last position $(\bar{x}$ $=2$. $93, \sigma=.95) \cdot \bar{x}$ - arithmetic average, $\bar{x}=\frac{\sum x}{n}$, where $\Sigma \mathrm{x}$ - sum of values, $\mathrm{n}$ - sample size; $\sigma$ - standard deviation, $\sqrt{\sigma^{2}}$, където $\sigma^{-}$ standard deviation of the mean square deviation of the random variable $X$ related to its mathematical expectation; $\sigma^{2}$-variability.

For the closed-ended question, a Likert scale of five points was used from 1 "unimportant" to 5 "very important" to assess the importance of each item. The Cronbach's alpha coefficient for the scale was 0.809 , indicating that the internal consistency and validation of the instrument is good.

\subsection{Semantic differential on the landmark micro destination of the "Old Town" of Plovdiv}

For the purposes of this research paper, an implementation of the method of semantic differential on the landmark micro destination of the Old Town of Plovdiv which examines the conception of the mark and the associations it evokes, a list of ten pairs of adjectives antonyms has been developed as seen in Figure 1. In the thus applied scale, the scores standing closest to 1 correspond to the highest score, and are oriented towards the adjectives found in the left column, respectively, while the scores closest to 5 correspond to the lowest score, and lead to the adjectives in the right column, respectively.

Figure 1. Semantic differential for the city of Plovdiv and a "dream" destination for cultural tourism used for comparison

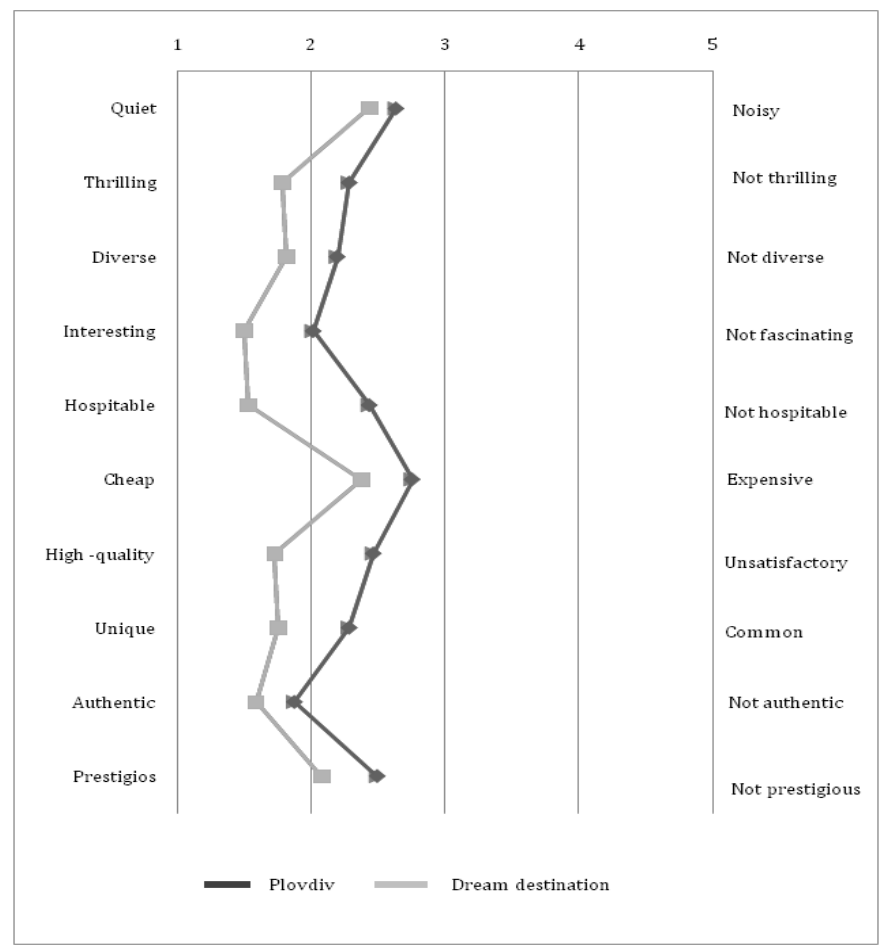

Source: Authors' own calculation (2014), based on the data of the performed questionnaire survey. 
The analysis of the cultural profile in a logical plan should make clear the regional identity and authenticity and unique features of the destination, as it is these three aspects that to a great extend determine the profile itself. Of course the image of the destination has its significant place in terms of the image associated with the tourist destination in perceptions of the tourists and that ultimately is a kind of catalyst for the tourism demand. Looking at the cultural profile as a symbiosis between regional identity and authenticity, unique features and image, attention should be paid to communicating the profile, and the provision of information on tourist offer of the destination.

Evidently, for tourists apply the findings where the pair "cheapexpensive" is not of paramount importance. The rating of 2.38 for cultural tourism dream destination comes close to the curve of "cheap" and it can be stated that is halfway between cheap" and "expensive", which clearly speaks of its importance given by the tourists. Nevertheless, the landmark micro destination of the socalled "Old Town" (the ancient town) of Plovdiv was assessed by the respondents as more expensive (with a rating of 2.76) of their dream destination. These results demonstrate that probably Plovdiv is still of no interest to the cultural tourists group according to the specific characteristics of cultural tourism users which represent a group with high solvency whose destination selecting decision is influenced in a considerably lower extent of the cost factors.

Following that, the greatest degree of approximation of both curves have is observed in the pair "authentic- not authentic " respectively with rating 1.88 for Plovdiv and 1.59 for the dram destination, which means that Plovdiv has been highly rated in terms of authenticity, which in turn is significantly important component of the cultural profile of the destination. Once more we determined the greatest deferral between the two curves (i.e. the greatest difference in the ratings between Plovdiv and the dream destination) in the pairs "hospitable - not hospitable" (respectively 2.44 and 1.53) and "high-quality - unsatisfactory "(respectively with ratings 2.47 and 1.73 ).

Moreover, the results of the dream destination vary in the range between 1 and 2 as only for pairs "quiet - noisy" and "cheap expensive" they are between 2 and 3 . The figures for Plovdiv are in the range between 2 and 3 for the pair "authentic - not authentic" as the curve lies between 1 and 2 .

Finally, an apparent evidence from the semantic differential is that the two curves do not derives in a very receding, i.e. we have not observed widely varying rating, which demonstrated the potential that the landmark micro destination Plovdiv possess in order to become an attractive destination for cultural tourism and establish sharply recognizable cultural image.

\section{Conclusions}

Undoubtedly, the destination attractiveness is key element in its identification and recognition. As established and appointed by the results of the above presented independent studies which met at rugged point in and can set conclusions in two main directions.

First for the results from the evaluation and analysis of the cultural profile of the landmark micro destination of Plovdiv, they show the need of a change in terms of formation of a more distinct cultural profile, as well as in terms of its communication. Diversifying the cultural touristic offering, improvement of the informational servicing, change in the design of products of cultural tourism are some of the steps which should be taken to achieve higher degree of satisfaction in the practicing this kind of tourism, as well as for positive change and strengthening of the cultural profile of the destination itself. These changes could be implemented more successfully when applying a strategy adapted to and oriented to the cultural profiling, and which is to be reflected in the creation of an action plan for adjustment, maintenance and affirmation of the cultural profile. Of course, the efficiency of the plan, i.e. the results achieved by its implementation, should be viewed in shortterm and long-term perspective. Increase of the number of visitors may be expected in a shorter term, but the adjustment of the profile in the mind of consumers is a long process which takes more time, and these results may be rather expected in long-term perspective.

The second one, reflects the current tourism industry demands destinations and even possibly lead to the depletion of such areas, following destination development process and seasonally concentrated mass use, can jeopardise their attractiveness if the performed tourist activities are not strategically managed and their carrying capacity is not taken into consideration. Furthermore, attractiveness' increasing and image recognition of Bulgaria as a tourism destination may be achieved by embodying its cultural attributes as a branding as evident from the represented here case of the landmark micro destination. On the other hand, branding Bulgaria as unique attractive cultural destination may help its market placing as year-round destination. All the above, requires for all stakeholders actively to participate in these processes. Attractiveness management should be structured by strategy polices aiming at attracting visitors who are inclined to perceive our distinctive national identity, our cultural traditions and pristine nature combined all together in a positive, attractive image of tourist destination Bulgaria. In the case of destination Bulgaria, emphasizing on its cultural attributes should be primary or leading, moreover they are highest rated by the respondents which can relate to the unique cultural regional identity of the dream tourist destination image establishment mentioned by the respondents. This will not only increase tourist destination Bulgaria brand recognition but it may supplement of its direct competitors in the competitiveness race.

\section{References}

Andersson, T. D., \& Getz, D. (2009). Tourism as a mixed industry: Differences between private, public and not-for-profit festivals. Tourism Management, 30, 847-856.

Benckendorff, P. and Pearce, P. L. (2003). Australian tourist attractions: The links between organizational characteristics and planning. Journal of Travel Research, 42, 24-35.

Caldwell, N. \& Freire, J. R. (2004). The difference between branding a country, a region and a city: Applying the Brand Box Model. Journal of Brand Management, 12 (1), 50-61.

Chen, J. S., \& Hsu. A. H. C. (2000). Measurement of Korean tourists' perception images of overseas destinations. Journal of Travel Research, 8(4), 411- 416.

Gearing, C. E, Swart, W. W., \& Var, T. (1974). Establishing a measure of touristic attractiveness. Journal of Travel Research, 12, 1-8.

Becker, C. (1992). Kulturtourismus eine zukunftsträchtige Entwicklungsstrategie für den Saar- Mosel- Ardennenraum. In C. Becker \& A., Steinecke (Eds.), Perspektiven des Tourismus im Zentrum Europas (pp. 57-60). Trier: ETI.

Bieger, T. (2002). Management von Destinationen. München: Oldenburg. 
Bieger, T., Pechlaner, H. \& Steinecke, A. (Hrsg.) (2001). Erfolgskonzepte im Tourismus. Marken - Kultur - Neue Geschäftsmodelle. Wien: Linde.

Bourdieu, P. (1986). The forms of capital. In J. Richardson (Ed.) Handbook of Theory and Research for the Sociology of Education (pp. 241-258). New York: Greenwood).

Bulgarian Wine Tours. (2016). Plovdiv - 8000 years of history in 1000 words. Retrieved June 10, 2016 from http://bulgariawinetours.com/plovdiv-8000years-of-history-in-1000-words/\#prettyPhoto/1/.

Ferrario, F. F. (1979). The evaluation of tourist resources: an applied methodology. Journal of Travel Research, 17(3), 18-22.

Formica, S. (2002). Measuring destination attractiveness: A proposed framework. Journal of American Academy of Business, 1(2), 350-355.

Formica, S, (2000). Destination attractiveness as a function of supply and demand interaction. Virginia: Blacksburg.

Fridgen, J. D. Ritchie, J. R. B., \& Zins, M. (1978). Culture as determinant of the attractiveness of a tourism region. Annals of Tourism Research, 5, 2833.

Funk, D. C., Ridinger, L. L., \& Moorman, A. M. (2004). Exploring origins of involvement: Understanding the relationship between consumer motives and involvement with professional sport teams. Leisure Sciences, 26 (1), 35-61.

Gearing, C. E, Swart, W. W., \& Var, T. (1974). Establishing a measure of touristic attractiveness. Journal of Travel Research, 12, 1-8.

Hair, J. F., Tatham, R. L., Anderson, R. E. \& Black, W. (1998). Multivariate data analysis (5th Edition). New Jersey: Prentice Hall.

Hair, J.F., Black, W.C., Babin, B.J., \& Anderson, R.E. (2010). Multivariate data analysis. Seventh Edition. Prentice Hall, Upper Saddle River, New Jersey.

Hu, Y., \& Ritchie, J. R. B. (1993). Measuring destination attractiveness: a context approach. Journal of Travel Research, 32(2), 25-36.

Hu, W., \& Wall, G. (2005). Environmental management, environmental image and the competitive tourist attraction. Journal of Sustainable Tourism, 13(6), 617-635.

John-Grimm, M. (2006). Tourismus - Destinationen zwischen Profilierung und Austauschbarkeit: Ein geographischer Diskurs zu den aktuellen Herausforderungen auf dem Tourismusmarkt am Beispiel der Destination Hamburg., (Doctoral dissertation, University of Hamburg: Inst. für Geographie 2006). Retrieved June 05, 2016 from http://ediss.sub.unihamburg.de/volltexte/2006/2886/pdf/Publikation online.pdf

Kotler, P., \& Armstrong, G. (2014). Principles of marketing person education. (2nd ed.). Cambridge: Pearson.

Leask, A. (2010). Progress in visitor attraction research: Towards more effective management. Tourism Management, 31, 155-166.

Lue, C.-C., Crompton, J. L., \& Stewart, W. P. (1996). Evidence of cumulative attraction in multidestination recreational trip decisions. Journal of Travel Research, 35(1), 41-49.

Mariani, M. M., Buhalis, D., Longhi, C., \& Vitouladiti, O. (2014). Managing change in tourism destinations: Key issues and current trends. Journal of Destination Marketing \& Management, 2(4), 269-272.

Mariani, M. \& Kylanen, M. (2014). The relevance of public-private partnerships in coopetition: Empirical evidence from the tourism sector. International Journal of Business Environment, 6(1), 106-125.

Mayo, E. J. \& Jarvis, L. (1981). Psychology of leisure Travel. Boston: C.B.I Publishing.

Middleton, V. T. (1989). Marketing implications for attractions. Tourism Management, 10(3), 229-232.

Ministry of Economy, Energy and Tourism. (2008). Studies of ten generating markets, Project No. BG 161P0001 / 3.3-01 / 2008 / 001-1 "Marketing research and evaluate the effectiveness of national marketing". Retrieved June 05, 2016 from: http://old1.mee.government.bg/files/useruploads/files/turism__statistika_i_analizi/prouchvania_proekti/country_report_ru_bg.pdf

Ministry of Economy, Energy and Tourism. (2007). "Unification of Bulgaria brand" for the project "Developing a brand strategy for Bulgaria and putting into practice integrated and consistent brand management. Operation Programme "Regional development "2007-2013. Retrieved June 10, 2016 from http://www.mi.government.bg/files/useruploads/files/vop/brand_resear ch.pdf

Morachat, C. (2003). A study of destination attractiveness trough tourist's perspective: a focus on Chaing Mai, Thailan. (Doctoral dissertation, Edith Cowan University, Western Australia 2003) Retrieved June 10, 2016 from: http://ro.ecu.edu.au/cgi/viewcontent.cgi?article=2505\&context=theses

Nunnaly, J, C. (1978), Psychometric Theory. (2 $\left.{ }^{\text {nd }} e d.\right)$. New York: McGrawHill.

Plovdiv Airport. (2016). Plovdiv Airport - The South Gate of Bulgaria: Guide - Visit Plovdiv. Retrieved June 10, 2016 from http://www.plovdivairport.com/bg/patevoditel-info/posetete-plovdiv

Richards, G. (2001). Cultural attractions and European tourism. Wallingford: $C A B I$ International.

Ritchie, J. \& Zins, M. (1978). Culture as determinant of the attractiveness of a tourism region. Annals of Tourism Research, 5(2), 252-267.

Steckenbauer, C. (2004). Kulturtourismus und kulturelles Kapital. Die feinen Unterschiede des Reiseverhaltens. Zeitschrift für Kulturwissenschaft, 15(Juni), 1-27.

Steinecke, A. (1994). Kultur und Tourismus: aktuelle Forschungsergebnisse und künftige Forschungs- und Handlungsfelder. Zeitschfift für Fremdenverkehr, 49(4), 20-24.

Stankova, M. (2006). Alternative tourism. Blagoevgrad: University Publishers „Neofit Rilski”.

Tang, J. C., \& Rochananond, N. (1990). Attractiveness as a tourist destination: a comparative study of Thailand and selected countries. SocioEconomic Planning Sciences, 24(3), 229-236.

Terziyska, I., \& Kyurova, V. (2013). Characteristics of benchmarking in tourism. Entrepreneurship, 1(1\&2), 33-40.

Vester, H. G. (1999). Tourismustheorie. Soziologische Wegweiser zum Verständnis touristischer Phänomene. München: Profil Verlag.

Var, T., Beck, R. A. D., \& Lofius, P. (1977) Definition of touristic attractiveness of the touristic areas in British Columbia. Journal of Travel Research, 15 (3), 23-29

Vester, H.-G. (1993). Authentizität. In H. Hahn \& H. J. Kagelmann (Eds.)Tourismuspsychologie und Tourismussoziologie (pp. 122-124). München: Quintessenz Verlag.

Wöhe, G. (2000). Einführung in die Allgemeine Betriebswirtschaftslehre. München: Vahlens Handbücher der Wirtschafts- und Sozialwissenschaftler.

World Travel \& Tourism Council (WTTC). (2014). Travel and Tourism Economic Impact World, 2014; Retrieved May 25, 2016 from: http://www.wttc.org/-/media/files/reports/economic\%20impact\%20 research/ regional\%20reports/world2014.pdf

Received: 05 June 2016

Revisions required: 10 November 2016

Accepted: 20 January 2017 